\title{
Empowering Transliteracy in the School Library Through International Collaboration
}

\author{
Nevenka Mandelj \\ nevenka.mandelj@guest.arnes.si \\ school librarian, Slovene teacher, mentor of extracurricular activities and National eTwinning ambassador
}

\section{Urša Bajda}

ursa.bajda@guest.arnes.si

master of librarianship and information science, school librarian, president of Section for school libraries in Slovenian Association of Librarianship

Keywords: School libraries, international projects, transliteracy, International school library month, Erasmus +

\begin{abstract}
In the field of Slovenian school libraries, we join many of those wide spaces of literacies through our international cooperation between schools involving pupils in different multicultural and international activities. For this occasion, we will represent two examples of Empowering Transliteracy in the School Libraries of Slovenia. The first one involves activities of transliteracy in the school curricula by celebrating International School Library Month, which takes place every October. The second example of empowering Transliteracy in the School Library was established in the Elementary School Litija through Erasmus plus activities. Not only do these activities strengthen all levels of competence of modern times, but as we strongly believe, help creating critical readers who will insist on lifelong learning.
\end{abstract}

\section{Introduction}

Professionals of Literacy agree that we are still quite far from the knowledge of meta literacy and the adoption of literacy-related cognitive processes. However, these processes seem to be efficient to teach basic literacy without special additional behaviour, without study programs that would make these behaviours systematically mediated, and without specific linguistic-oriented literacy research. In Slovenia and internationally, questions about knowledge appear, which are necessary for reading, understanding and understanding new forms in virtual spaces. So called digital literacy and its various forms insights in addition to understanding electronic or digital literacy change the basic linear form reading from word to word, from the first page to the last one in the linear order. However, digital literacy does not mention the reading processes that are necessary for effective understanding of electronic texts. It does not touch, however, the questions why it requires familiar reading processes for successful reading of electronic words that are characteristic of digital literacy and are needed to effectively understand various forms of electronic texts. (Grosman, 2011) 
Thinking about the literacy of or about the literacy, guides us to meta literacy and further to the term transliteracy.

There is a wide range of literacies. We compare it with multiple intelligences by Gardner: Visual-Spatial, Bodily-kinaesthetic, Musical, Interpersonal, Intrapersonal, Linguistic, Logical -Mathematical - reasoning. Is it possible to transform them to »literacy space«, like Visual-Spatial literacy, Bodily-kinaesthetic literacy, Musical literacy, Interpersonal literacy, Intrapersonal literacy, Linguistic literacy, Logical -Mathematical - reasoning literacy? We think it is possible, but that will take part and place in another research.

In the field of Slovenian school libraries, we join many of those wide spaces of literacies through our international cooperation between schools by involving pupils in different multicultural and international activities. For this occasion we will represent two examples of Empowering Transliteracy in the School Libraries.

\section{Objectives of the Presentation}

As we explore topics and themes about empowering transliteracy in the field of school librarianship, by reading articles and reports of professionals and researchers of that scientific field, we recognise that by involving students, teachers and ourselves into learning process through international projects, we are contributing to an overall Transliteracy empowerment. As an explanation of what Transliteracy is, we agree with the theory, that Transliteracy is an ability to use diverse analogue and digital technologies, techniques, modes and protocols

- to search for and work with a variety of resources

- to collaborate and participate in social networks

- to communicate meanings and new knowledge by using different tones, genres, modalities and media. (Sukovic, 2016)

Furthermore, Transliteracy includes skills, knowledge, thinking and acting. These enable a fluent movement in a way that is defined by situational, social, cultural and technological contexts.

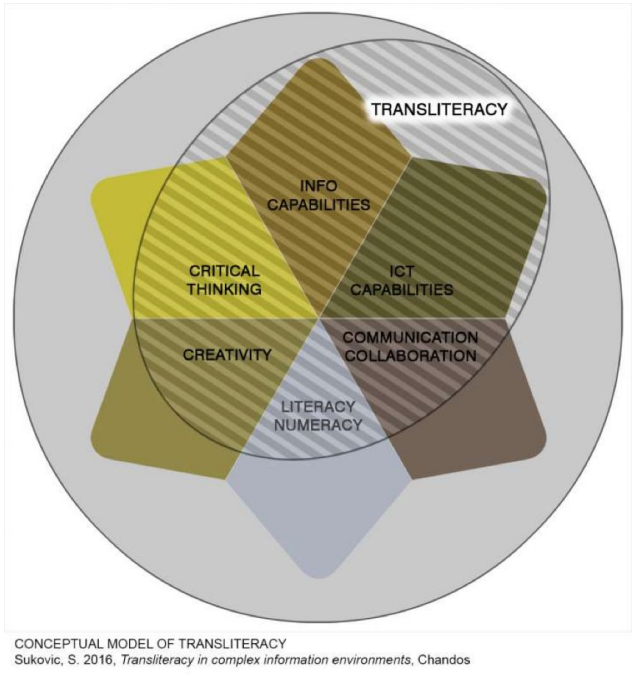

Since transliteracy is based on information and ICT capabilities, it primarily appears in information and technology rich environments. It also encompasses creativity, critical thinking, as well as communication and collaboration. These are the main skill and knowledge components of transliteracy. These defining components are not situated wholly in the transliteracy framework as they can be observed regardless of 
transliteracy. Literacy and numeracy underpin transliteracy in the same way they enable any learning. (Ibid)

\subsection{Transliteracy in the school curricula through celebrating International School Library Month}

The first example is involving activities of transliteracy in the school curricula through celebrating International School Library Month, taking place every October.

In Slovenia, all project at ISLM are traditionally coordinated by the Section for School Libraries at the Slovenian Association of Librarianship. In October we invite all Slovenian school libraries and librarians to join and celebrate.

In 1999, librarians began to celebrate their international day on the fourth Monday in October; in Slovenia, it was first celebrated on 22nd October 2007. In 2008 the committee decided to adapt the celebration to the local environment as more and more countries joined the celebration. James Henri, president of the IASL, noted that the International School Libraries Day had actually grown into an international month of school libraries. This means that librarians can choose either a day or a week or even the entire month and carry out activities dedicated to the library and stress the meaning of the school library to the school community. The International Month of School Libraries allows school librarians to choose a day in October, which best suits their individual situation to festively emphasize the importance of school libraries.

By celebrating, we want to draw the Slovenian public's attention to the work of school libraries and to highlight their importance in acquiring and connecting knowledge, empathy, training children's, pupils' and students' social skills and establishing a positive attitude towards libraries and reading. Through all those activities we are empowering Transliteracy of local communities and wider - internationally.

Each school sends a report of activities their users attended and those reports are sent to the national coordinator - me. Every January (for the last three years), I made and published electronic publication of all reports. These are available here:

- $\quad$ Mednarodni mesec šolskih knjižnic 2018 = International school library month 2018

- Mednarodni mesec šolskih knjižnic oktober 2017 = International school library month $\underline{2017}$

- $\quad$ Mednarodni mesec šolskih knjižnic 2016 = International school library month 2016

How to promote Empowering Transliteracy in the School Library through activities of International School Library Month? The ideas can be chosen from the following suggestions:

- A discussion of pupils and school staff about the importance of school libraries for learning and teaching.

- An encouragement of reading in a wide variety of ways by:

- preparing a fairy tale event with pupils - for young readers and locals there is a creative workshop with storytelling and creative activities;

- preparing a workshop for parents on how to motivate parents to read with their children;

- organizing a conversation with the readers: a tea party for teachers and parents;

- for the public, organizing a presentation of a research / project tasks, involving a school library with resources and learning about the use of resources;

International Association of School Librarianship

https://iasl-online.org 
- $\quad$ organizing a book fair where books and authors from other countries are presented.

- Through joint projects with other schools, pupils create posters, leaflets, mouse pads, and the like to represent the importance of the school library. Creations can be used for New Year gifts.

- An exchange of bookmarks among Slovenian school libraries. Registration is possible by the 8th October at the NATIONAL BOOKMARKS EXCHANGES link.

- We participate in the international exchange of booklets and bookmarks as a part of Bookmark Exchange Project. Students exchange the booklets and bookmarks with peers around the world. First, you need to make a registration. Then, the ISLM International Coordinator grants you a partner school (last week in September). Finally, you are notified by e-mail.

- An invitation of an important guest to talk about the importance of the school library and present the work students do in the library, etc.

- Collaborate with the general library and prepare a common event that can be presented in November on the day of public libraries.

\subsection{Empowering Transliteracy in the School Library Through Erasmus + Projects}

The second example of empowering Transliteracy in the School Library was established in the Elementary School Litija.

For the last 10 years the motto of the school library in the Elementary School Litija has been Door to the library - door to the world, and on the entrance, we have a great inscription 'Where the adventure begins.'

The purpose of our school library is to help each member of the school community - students, employees and parents - acquire the new knowledge. This is important for preservation of lifelong learning.

We prepare children for life in a world that is also unknown to us, professions that do not even exist at all. As John Dewey said: "If we teach today's students as we taught yesterday's, we rob them of tomorrow."

We can rightly say that our school library is the heart of the school, the heart, which surely became beating strongly when we started joining international projects.

My dear colleague Urša Bajda got me acquainted with eTwinning, a platform for staff (teachers, principals, librarians, etc.) working in a school in one of the European countries.

eTwinning, which was established in 2005 as the main criterion of the European Commission's e-Learning Program, has been co-financed since 2014 from the Erasmus + European Program for Education, Training, Youth and Sport.

The portal gives us an ideal opportunity to meet virtually, exchange ideas and practice examples, learn together and engage in online-based projects in any subject area with educators involved in school education, including pre-school and vocational education. We can work on any topic we and our partner wish to work on. We do not need to be an advanced ICT user to be involved since one of the objectives of eTwinning is to improve our abilities in ICT and to make it part of daily life in the classroom or in our case in the library. 
Long story short: at this moment our school library has completed 49 international eTwinning projects, 8 are active in this school year. Students involved in activities are aged between 11 and 14 and are members of a library club called LibBros. During project, they became highly motivated, adventurous, creative, initiative and connected.

The quality work and efforts were fruitful: we are proud of 14 national quality labels and 10 European quality labels. In the years 2014 in 2016, we were also rewarded with National award Zlati kabel and in 2017 another National award Jabolko kvalitete.

In 2015, we made another big step. With a group of active teachers and pupils, we bravely entered the new Erasmus plus story: Key Action 2. Simply put, we have upgraded online project with live meetings in all countries participating in the project.

We quickly realized that this will not be our only experience. Next challenge was Erasmus plus: Key Action 1, which provided teachers in projects group with opportunities to study abroad.

Erasmus plus activities strengthen all levels of competence of modern times. I am convinced that by participating in these activities, as much as possible, I help to create critical readers who will insist on lifelong learning.

\section{Conclusion}

When finishing elementary school education, our pupil Lara said: »Participation in international projects has raised my self-esteem, helped me improve my language competences, brought numerous new friendships, gave me an insight into other cultures, habits and ways of life and increased my tolerance toward people who think differently. I am convinced that by participating in various international activities, I am fundamentally better prepared for a critical entry into modern society. Furthermore, I am richer for many sparkling and unforgettable anecdotes that have waved during the project.

Moreover, we all agree that that is far-reaching and even more beyond the transliteracy experiences.

\section{REFERENCES}

Grosman, M. (2011). Večrazsežna pismenost izziv sedanjosti. V: Razvijanje različnih pismenosti. Univerzitetna založba Annales: Koper, 2011. Str. 19-28.

Mednarodni mesec šolskih knjižnic 2018 = International school library month 2018. [on-line] https://issuu.com/knjinicaotonckecectrbovlje/docs/publikacija_2018

Mednarodni mesec šolskih knjižnic oktober 2017 = International school library month 2017. [on-line] https://issuu.com/knjinicaotonckecectrbovlje/docs/publikacija_islm_sekcije_olskih_k

Mednarodni mesec šolskih knjižnic 2016 = International school library month 2016. [on-line] https://issuu.com/ursa.baj/docs/publikacija_islm_sekcije_olskih_k

Sukovic, S. (2016). What Exactly is Transliteracy. [on-line] http://scitechconnect.elsevier.com/what-exactly-is-transliteracy/ 
International Association of School Librarianship

https://iasl-online.org 